\title{
TWENTY-FIRST ANNUAL NESTBOX REPORT FROM BRANDON, MANITOBA
}

MRS. JOHN LANE, 1701 Lorne Avenue, Brandon, Manitoba. R7A OW2 and MAMIE MCCOWAN, BARBARA ROBINSON, HAZEL PATMORE and ANN SMITH

The year 1981 was an exciting and rewarding one for the group of dedicated volunteers, "The Friends of the Bluebirds". The usual spring and fall get-togethers took place at the home of the co-ordinator, Norah Lane. Both meetings were well attended and new members were enrolled.

Janaury saw the first of many meetings of the planning committees for the Great Northern Plains Conference of the North American Bluebird Society. Lorne Scott, Indian Head, and Norah Lane, both Canadian directors of North American Bluebird Society, had responded to a request from headquarters in Maryland to organize a bluebird conference. With permission to hold it in Brandon University and with Dr. Roger Smith, Department of Zoology, as chairman of the committees formed from members of The Friends of the Bluebirds, Brandon Natural History Society, and faculty and staff at Brandon University, a fine program was planned for June 25-28.

One hundred and sixty-six people registered, representing nine American states (Maryland, Pennsylvania, Wisconsin, Virginia, Georgia, Missouri, Indiana, Montana and Oregon) and four Canadian provinces (Ontario, Manitoba, Saskatchewan and Alberta); and there were two people from England.

Field trips along the Carberry-Spruce Woods nestlines to observe nesting Mountain and Eastern Bluebirds and Tree Swallows and on to the Souris River Bend Wildlife Management Area to observe other species gave the conference a good start. Lectures, a nature art exhibit, displays of nestline maps and bluebird-related items, books and souvenir shop, and a wind-up banquet, were other highlights, interspersed with coffee breaks and exchanges of bluebird experiences.

Dr. Lawrence Zeleny, founder of the North American Bluebird Society, Mary Janetatos, Executive Director, and Chuck Dupree, Treasurer, all of Maryland, spoke of the history of bluebird conservation in North America and told of the work of the Central Office, Maryland. Speakers on the topic of bluebirds in their areas were Herbert Prescott, Portland, Oregon; Duncan Mackintosh, Lethbridge; Norah Lane, Brandon; Don Stiles, Calgary; Art Aylesworth, Ronan, Montana; Lorne Scott, Indian Head; Richard Rounds, Brandon. Adding variety with lecture topics on other bird life were Phil Horch, Winnipeg; Stuart Houston, Saskatoon; Fred McGuinness, Brandon; Robert Nero, Winnipeg.

Leaders for the field trips, including those special Sunday morning ones, were Peter Sawatzky, Barbara Robinson, Herb Goulden, Mamie McCowan, Kae Longrigg, Cliff Findlay and Dick Rounds.

Meeting bluebirders from across the continent made us aware of the value of the North American Bluebird Society. And because Brian Shantz of Nanton, Alberta, is our new Canadian director, we look forward to a possible regional meeting farther west.

In our local area three important research projects on our nestlines have added scientific interest and results.

Hugh Munro completed his Master's program. A copy of his thesis published by the University of Manitoba, titled "An 
Analysis of Use of Nest Boxes by Mountain Bluebirds in Southwestern Manitoba", is in our hands, a gift from him.

Two summer projects set up by Dr. Richard Rounds and Dr. Roger Smith, Brandon University, were carried out by undergraduate students. Judy Hickson, Geography student, experimented with micro-climate of artificial nest boxes. There were 72 boxes of 24 different designs. Linda Macson, Zoology student, made observations of the behavior of Mountain Bluebirds at three nest boxes in each of two different habitats. It is hoped that the results of the research by these two students will be published.

The Auk accepted and published a paper "The Fertility of Albinistic Eggs", by Richard Rounds, Donita and Hugh Munro.

The Wilson Bulletin published "A Review of Hybridization in Sialia", by Richard Rounds and Hugh Munro.

A CKX-TV half-hour Wildlife Special featuring Dr. Richard Rounds on the bluebird nestlines in Southwestern Manitoba, proved a huge success. CKX has received requests from viewers to have it repeated over their stations.
Reporting on the work of The Friends of the Bluebirds, a summary of nesting success in monitored boxes during 1981 is given in Table I. The numbers are similar to those reported for 1980 but the two years are not directly comparable as some of the nest boxes and nestlines were different in the two years. The apparent increase in mice is due to increased reports outside of the bluebird nesting season from the early spring and the fall clean-up of boxes.

Again the Eastern Bluebird seemed to be concentrated in the sandy areas of the Carberry and Lauder Sandhills. It is interesting to note that Mr. and Mrs. J.B. Thomas, Hartney, reported three boxes where two broods of Eastern Bluebirds were raised.

Another case of hybridization was reported, this one by Peter Sawatzky in box No. 677 on the Carberry-Glenboro line. A Moutain Bluebird female and an Eastern Bluebird male successfully raised six young hybrids.

Other occupants of the nest boxes included a Chipping Sparrow, wasps and Thief Ants (Solenopsis molesta). The ants were in a nest box under observation by Linda Macson and were observed on extremely thin shelled eggs

Table 1. OCCUPANCY OF NEST BOXES IN THE BRANDON, MANITOBA, AREA - 1981

Occupant

Number of nestings

Mountain Bluebirds

727

Eastern Bluebirds

Bluebirds (not identified to species)

Cross Nesting Bluebirds (Eastern x Mountain)

Tree Swallows

House Sparrows

178

House Wrens

Starlings

Mice

Squirrels

Others: Thief ants, wasps, Chipping Sparrow and unidentified sparrow 
